Article

\title{
Rules of Engagement: A Review of Regulatory Instruments Designed to Promote and Secure Local Content Requirements in the Oil and Gas Sector
}

\author{
Berryl Claire Asiago \\ Centre of Climate Change, Environmental and Energy, University of Eastern Finland (UEF) FI-80100 Joensuu, \\ Finland; Berryl.asiago@uef.fi
}

Received: 9 April 2017; Accepted: 22 August 2017; Published: 6 September 2017

\begin{abstract}
Regulatory interventions, such as Local Content (LC) requirements, have been incorporated to counter market forces to maximise petroleum revenues. This has been undertaken with the hypothesis that the governments of petroleum-producing countries depend heavily on petroleum sectors for development, yet energy markets inadequately allocate these resources. Thus, governments revise existing, and often out-of-date, petroleum laws and introduce new petroleum legislation to specifically promote socio-economic objectives. This article explores the key legislative instruments of LC as developed and implemented in the oil and gas sectors both from developed and developing countries' perspectives. In assessing the overall policy approach, this article evaluates instruments used to secure Local Content requirements in the oil and gas industry. In conclusion, governments must identify appropriate frameworks that consider the political and regulatory challenge of striking a balance between incentivising upstream investors and fulfilling national interests, such as creating jobs.
\end{abstract}

Keywords: petroleum regime; Local Content Requirements; regulation; natural resources; Norway; Nigeria; Angola

\section{Introduction}

Thomas Walde's (2008) questions "If instruments of good governance and the rule of law have any significance when faced with the force of the energy and resource industries cycles?", to which he concludes that renegotiation demands are prevalent where states view the lack of a balanced internal system. Hence the need to revise frameworks to achieve a politically and legally acceptable outcome for the host state [1], exemplifies the present scenario in the oil and gas sectors, with national governments reintroducing national strategies aimed at the long-term sustainability of the industry by prioritizing the social and economic benefits of petroleum extraction [2]. This has been undertaken amidst the successful implementation of socio-economic goals using legal and regulatory frameworks in Norway [3]. Thus, many governments are overhauling existing, and often outdated, petroleum laws and introducing new petroleum legislation to specifically promote socio-economic objectives [2]. The legislative and regulatory interventions have resulted, in many cases, in an introduction of performance requirements commonly known as "Local Content" (LC) requirements [4]. These requirements are often described as investment measures [4], which specifically involve preferential market access [5] to domestically manufactured goods, and are aimed at increasing local participation in an industry [2].

Currently, LC introduction is considered within the ambit of petroleum regulatory frameworks. They are utilized to maximize petroleum revenues [6], create local jobs [7], foster industrial development [8], resolve community conflicts [9], and enhance the social and economic impacts of procurement strategies [10] and the transfer of technology, among others [3,7]. In addition, these LC objectives are considered despite market trends and economies of scale (which often give preference to 
global supply chain networks over locals) [4]. Notably, the imposition of these objectives indicates that states attempt to consider many inter-related factors that are not specifically petroleum sector-related, which questions the effectiveness of petroleum regulatory mechanisms in developing LC mandates. Thus, this article contends that LC has become a more regulatory and institutional ambiguity rather than a resource industry cycle concern. This hypothesis stems from the perceptions that International Oil Companies "IOCs" benefit from the terms of their contracts irrespective of the climate of high energy prices [7], as identified in research conducted by United Nations on Convention Trade and Development (UNCATD) (2010) that extraction companies, particularly in the energy sector, have enjoyed record profits over the years [7]. Paradoxically, the areas where these extractions occur, especially in developing countries, remain heavily pillaged in poverty [11]. Additionally, the citizens of most oil-producing countries continue to live below the poverty line despite an abundance resources [12], which suggests that resource revenues have yet to benefit those citizens at large [13].

This analysis suggests that energy markets inadequately allocate resources in favour of IOCs, yet these are the very sectors that resource-rich countries heavily depend on for development [12]. Hence, this unfair distribution of revenue prompts governments to revise petroleum systems to enhance local participation for potential economic growth and development. This indicates the crucial role LC's play in developing an industry. However, LC interventions (especially from developing countries) have become unpopular [14] with foreign investors, who cite a breach of the rule of law in relation to long-term resource investment [4] and an impossibility of performance due to inadequate resources (human, financial, and technical skills) [2]. This is contrary to developed producing countries (U.K., U.S., or Norway), where the use of such interventions is embraced [8]. Governments of developed countries regularly adjust their tax and regulatory systems to benefit from industry [15]. Notably, as some scholars argue "these adjustments consider the relative profitability of the industry (and thus the size of the 'resource rent' available for taxation), which is normally quite responsive to the price levels. Or the need of conservation policies aimed at the long-term sustainability of the industry as well as evolving practices, standards, and political expectations with respect to local benefits, safety, or the environment" [15]. Consequently, IOCs continue to invest in developed jurisdictions with an expectation that although the regulatory regime will be revised, such adjustments will be made 'reasonably' and often in consideration to energy trends $[15,16]$. Note the fact that, despite the objectives of an intervention, developed governments seem to consider not only energy trends and industrial development issues, such as skill sets, financial assistance, industry information, and infrastructure, but to also factor in considerable regulatory frameworks that maximise order while simultaneously enhancing economic growth [16]. For instance, in Norway, where initial LC introduction was not very welcome, the establishment of additional mechanisms, such as responsive regulatory frameworks (principles-based regulations) and the incorporation of a functional institutional design that considers pertinent issues, such as skill set, political will, and economic incentives, influenced the successful implementation of LC $[17,18]$. Consequently, it leads to a successful LC Norwegian model with many countries attempting to imitate the design [18], demonstrating the necessity of appropriate legal and regulatory frameworks in developing LC mandates.

Naturally, the desire to imitate the Norwegian success has led many governments to revise their petroleum regimes. Regrettably, these revisions have maintained the conventional frameworks that rely on command and control systems, commonly known as rule-based regulations [19]. Rule-based regulatory frameworks tend to be prescriptive and focus mainly on compliance/deterrence mechanisms to influence market forces, but often fail to realise the policy objective or mitigate legal and political concerns [19]. This is because they give the impression that investors comply with related obligations, yet often investors only identify creative ways to show compliance [20], signifying that regulatory intentions are never actually achieved; thus, governments only favour the use of rigid regulatory power to compensate for weaknesses in markets. The challenge with this hypothesis is that governments ignore efficient policies that maximise order and have actual spill-over effects [21]. In addition, developing countries continue to ignore pertinent issues, such as inefficiencies related 
to industrial development (skill sets, financial assistance, industry information, and infrastructure), which have greater influence in the success or failure of LC than energy markets [14]. Those that, if well-developed, can sustain the industry by mitigating resource industry cycle challenges and the overall economy. It is no wonder that the introduction of these regulations have been met with mixed results that are often counterproductive to the intended objectives [2].

Therefore, this article advocates that the gap between the profits of operating companies and local economic benefits is likely to widen if governments do not consider appropriate frameworks to capture and retain value created from the industry [7]. Thus, governments need to identify appropriate frameworks that consider the political and regulatory challenge of striking a balance between incentivising upstream investors and fulfilling national interests, such as creating jobs. Ideally, an industrial development/participation issue should be a concern addressed within industrial policy/frameworks, which is almost subsidiary to trade policy. However, most trade and investments debates downplay the role and scope of industrial policy, making it a lot easier for governments to ignore the benefits associated with industrial policy/development. This indicates the extreme difficulty associated with ensuring appropriate policies have greater effects [22]. Nevertheless, where governments insist on fitting these mandates into petroleum regimes, then appropriate and responsive regulatory frameworks are required to maximise order while simultaneously enhancing economic development. Broadly, LC objectives have been expressed in overall or specific policy statements and/or economic plans. However, this study finds that the main regulatory instruments used in practice are often detailed within substantive or procedural petroleum legislation, as well as in negotiated contracts (licensing/concession, production sharing).

\section{Scope and Methodology}

The aim of this article is to focus on the role of legal instruments in place to foster economic and social objectives using LC mandates in petroleum upstream sectors. The approach undertaken is in consideration to three questions;

(a) What are the general aims of LC requirements (without being country specific)?

(b) Which instruments are often used to foster and achieve those aims and are there any limitations?

(c) Are the instruments necessary, suitable, or reasonable?

First, this article recognises that question one is broad ranging, since most LC requirements depend on the objectives of an individual regulation and/or the characteristics of a given petroleum sector. Nonetheless, Section 3 of this article attempts to identify and distinguish the general aims concerning LC rules by categorising these objectives into economic, social, and political aims. Specifically, discussions will be undertaken through socio-legal research, which considers the transformation of socio-economic objectives through law and thereby perceives law as a means of achieving socio-economic justice and parity.

Secondly, the article will focus on question two and three respectively, which, unlike question one, are deemed more objective because they evaluate and review prevailing instruments used to implement LC requirements and test the suitability or reasonability aspect of such measures. Thus, utilizing doctrinal methodology, which includes policy concepts, legal doctrines, and judicial pronouncements. Section 4, rules of engagement, will provide a survey of legal instruments relevant to LC development. This section will discuss various channels through which governments have opted to engage the sector in implementing LC requirements. These include binding and nonbinding instruments, which will be evaluated around legislative propositions, policy matters, and substantive and procedural laws, which are important in considering the justifications and outcomes for the socio-economic objectives of LC. Thereafter, Section 5 will deliberate on the suitability, reasonability, and necessity (appropriateness) test, which will be considered in relation to modes of regulation discussed within a fundamentally outcome-based approach, and anchored on principles-based regulation versus a compliance/deterrence-based approach, which is strongly anchored on rule-based 
regulation. The section will attempt to measure what model best suits individual developing countries by looking at other conventional legal materials, such as parliamentary debates, court decisions, and regulatory interpretations which concern the instruments in the choice of regulatory model. Finally, Section 6 will evaluate what realistic conclusion there is in developing LCs, indicating that despite petroleum being a global sector with inherent market forces, local issues remain significant to instituting protectionism schemes.

\section{LC Requirements and Objectives}

\subsection{Defining Local Content}

In broader sense, LC requirements are mandates imposed by government on investors to procure and/or support the growth of an industry [11,21,23]. Ideally, as a requirement, the objective of LC is to effectively expand local participation through creating local jobs or building local industries [24]. The rationale for such interventions is mainly to secure socio-economic concerns that ameliorate the lives of citizens, which in turn upgrades the economy of a country [7]. This is often achieved by recognizing the "skills problem" that is either financial, technical, or legal, and in turn dealing with the said gaps through incorporating joint ventures for IOCs to work with local personnel and companies [4]. This positive output, if successfully implemented, can play an important role in accelerating the process of economic growth and sustainable development in oil-producing countries, as was the case in Norway [17]. Importantly, such developments should be undertaken with limited interference to existing and potential investments [17].

The general challenge with these mandates lies in their definition and application. Currently, there is no universally agreed definition of the term "local", nor is there a consensus on what "content" should be covered in the petroleum sector [25]. Where LC is defined, it is often undertaken to reflect the objectives of the state (regulation) rather than the terminologies concerning "LC". For instance, in Nigeria, LC is based on the definition provided of "Nigerian content", meaning "the quantum of composite value added to or created in the Nigerian economy by a systematic development of capacity and capabilities through the deliberate utilization of Nigerian human, material resources and services in the Nigerian oil and gas industry" [26]. Emphasis has been laid on the key objective of LC, which is to increase local participation in the oil and gas sector and not the definition of the individual terms "local" or "content". Thus, defining LC requirements depends on the objectives of an individual regulation and/or the characteristics of a certain petroleum sector [23]. For instance, the underlying intention for Norwegian authorities to incorporate LC rules was "to develop domestic industrial competence that would contribute to national welfare even when the extraction of oil and gas no longer induce growth in the economy" [17]. Thus, LC rules are only significant if the resources would benefit the larger society and have locals play a leading role in the sector [27]. In relation to application, these legal mandates appear to heavily focus on the responsibility foreign investors have in developing local industry rather than the general investors pool including the local one. For instance, even though legal frameworks provide that these mandates apply to both foreign and local investors, the general practice as seen in Angola and Nigeria has leaned more to mandating foreign investors only.

Overall, these rules are deemed necessary for two reasons: first, to promote local participation, and second, to encourage foreign participation through investments [28]. The goal typology is to encourage foreign participation the short term with the view to have locals participate in the industry long term [17].

\subsection{LC Objectives}

This article categorizes LC objectives under two dimensions, one is in consideration to economics, and the other is on social objectives. These aims can be defined in different ways and be accorded different values. Notably, while there has been a decline in economic regulation, social regulation is 
on the rise. Overall, LC objectives vary extensively from country to country, and are often based on different strategic goals.

\subsubsection{Economic Objectives}

Economic objectives in a sector are varied and range from steady or sustained economic growth, to an increase of employment, to a balanced balance of payments, etc. Thus, LC rules will be incorporated as an intervention to remedy issues which may limit a country from attaining their economic objectives. Thus, interventions will be undertaken through economic regulations, which guides the structure and conduct of firms into an industry [29]. They are mainly exercised on ostensible natural monopolies and market structures often with imperfect or excessive competition [30]. Thus, the aim is to counter the negative welfare effects of a dominant position and behaviour through setting prices or conditions on the entry of firms to stabilize market processes [31]. Specifically, to the oil and gas sectors, LC is said to be a regulatory tool that seeks to correct market failure, often associated with foreign dominance, market power, or foreign market dominance, for instance.

LC is introduced to promote local business participation in an enclave environment, such as the petroleum industry. This is because the petroleum industry has distinct characteristics that tend to favour global supply chains with long-term contracts, which in turn preclude local participants [11]. Thus, intervention is often undertaken to mitigate the challenges encountered by local companies amidst the advantages enjoyed by foreign companies [4]. The fact is that international service providers have existing, well-established relationships with IOCs that give them an unfair advantage and makes it easy for them to work together [14]. This relationship has the unintended consequence of displacing small local firms from the value chain of the oil and gas industry [7]. Thus, without government intervention, local companies cannot effectively participate and be competitive [7]. For instance, the introduction of Norwegian Royal Decree 1972 witnessed the deliberate promotion of nationals in the sector through incorporating joint venture participations. Though not defined in the Law, LC provisions were administered under sections 53 and 54 of the resolution [32]. The provisions required investors to prioritize and utilize Norwegian goods if they were competitive in price and quality [17,23]. This was made under the assumption that IOCs had tendencies to use the well-established and long-term relationships among themselves, which would create biases against the use of local suppliers [17]. Thus, in support of the provisions, a special office, "The goods and service office", was established within the Ministry to ensure the condition was adhered to during the process of allocating licences and in the operations of oil and gas activities [17,32]. For instance, at the time of bidding, foreign companies could present Norwegian authorities with lists of their operators and the Ministry in consultation with 'The goods and service office' could also add to the list of operators a local company that measured in price and quality per the demands of the IOC [18,32]. Moreover, the Angolan authorities introduced the "Law for the promotion of business for local private companies 2003" (Law 14/03), which is annexed to the Petroleum Activities Law 2004. This legislation provides more opportunities for private national companies to play a significant role in the sector [33]. The decree was essential to mitigate the challenges often encountered by local companies in carrying out of activities in the oil sector [6]. These challenges included fiscal incentives, such as the exemption from and reduction of duties related to industrial and import incomes and other charges. Furthermore, financial support in the form of subsidies, loans, the promotional of venture capital, technical support, and special rights privileges was provided for. By doing so, the government introduced preferential treatment given to national private companies through Sonangol [34]. In Nigeria, the emergence of LC legislation in the form of the Nigerian Oil and Gas Industry Content Development Act, 2010 (the 'NOGICD Act') was to secure more indigenous participation in the industry [35]. The Act provides for preferential treatment for Nigerian independent operators as well as indigenous service companies. It provides that independent operators will be given first consideration in respect of the award of oil blocks, oil field licenses, oil lifting licenses, and contracts for new projects. Furthermore, the NOGICD Act provides that Nigerian indigenous service companies 
will have exclusive consideration in respect of certain contracts so long as the indigenous contractors demonstrate the ownership of equipment, Nigerian personnel, and capacity to execute such work.

A related point is the use of LC requirements to absorb local capacity, especially where local companies) have either technical or financial capacity (although limited) to carry out operations as allocated in the petroleum sectors. For IOCs, the limitation in capacity has the potential to create enormous delays in operations, hence IOCs will intentionally neglect locals and will prefer to fall back on established relationships to maximise their profit. Thus, government intervention is required to remedy this externality. For instance, Nigeria's Marginal Fields licensing round, as assigned by the Department of Petroleum Resources, was issued based on marginal fields that were left dormant over many years by IOCs. Department of Petroleum Resources was convinced that local companies with technical and financial capacity would benefit from developing them [36]. Thus, DPR issued the Guidelines for Farm-out and Operation of Marginal Fields 2013 (the 2013 Guidelines). The guidelines set out the procedure to be followed in the bidding for 31 marginal fields, of which 16 onshore and 15 offshore fields are available for indigenous companies (substantially Nigerian owned). Each indigenous applicant could only bid on a minimum of three marginal fields [36].

Finally, LC is also used to artificially increase the levels of local participation in a sector beyond levels that local capacity can meet. This objective is associated with inexperienced oil and gas industries that lack the specialised labour or pool of expertise required by the industry, consequently leading to an increase of foreign workers and service providers with the relevant skills and knowledge. The challenge with this vicious cycle is that the local labour force is never employed due to a lack of the required skills, but will never be able to gain that required expertise without opportunities to learn on the job. Thus, government intervention is used to ensure such skills are developed. In Angola, for instance, the introduction of the "Decree on rules and procedures" to regulate the recruitment, integration, training, and development of workers from the oil sector ("Decree-Law 17/09"), demanded that IOCs need to allocate a certain specified amount of training to nationals [34]. Additionally, the Decree on a general regulatory framework for the hiring of services and goods from national companies in the "Oil Industry-Decree 127/03" helped mitigate the challenges that involve the acquisition of capital and in-depth technical know-how by the training of locals to enhance their competence and skills $[2,33,40]$. Also, Nigerian authorities enacted subsidiary legislation, the Petroleum Training Institute PTI Act (Cap. 356). This entered force on 19 September 1972 with the intention to address, enhance, and promote courses of instruction, training, and research in the petroleum sector [3]. The understanding was that local capacity was not able to meet the operations, hence the need to increase its levels. Moreover, Norway introduced a "Training Agreement", which ensures that at the foreign company's expense, the national oil company has the right to demand a reasonable number of Statoil employees participate "for free" in the internal training programmes and the possibility for working in relation to the licensing of petroleum activities on the Norwegian Continental shelf [37].

\subsubsection{Socio-Political Objectives}

This is the search for the social optimum as argued by socio-legal scholars. Here, the objectives for regulation involve the correction of externalities that would normally have adverse effects to the public interest. The most common sectors comprise the environment, occupational health and safety, and consumer protection and labour (equal opportunities, etc.). Pertinent to the petroleum sector is the fact that local communities' grievances are mostly tied to demands for greater economic benefits, environmental protection, or land rights. These are often associated with environmental and social risks along the entire value chain (upstream to downstream). Such risks involve several factors, such as meeting the obligations to operate in local communities [2] independent of attaining a petroleum title (thus the need to attain a social licence to operate), and the need to equalise other adverse effects, such as conflicts, environmental degradation, negative disruption of agricultural activities, poor management of land, and economic inequalities, including expatriates' arrival, which makes 
living standards unbearable [7]. Therefore, obtaining a social licence to operate at the initial stages of operation, attaining political harmony and social cohesion during operations in conflict-related regions, or social compensation to those environmentally impacted have often been resolved through LC requirements [10]. For instance, although it is not entirely clear what the requirements for this social licence may be, in Australia a social licence to operate has become part and parcel of successful business practice $[38,39]$ and this has been achieved through LC instruments. Secondly, LC has been employed to resolve armed conflict and achieve a peaceful co-existence among communities, as well as limit conflict reoccurrence [9,40]. For instance, in Nigeria, the emergence of the indigenization policy often referred to as "Nigerianization" is legal framework that encourages the active participation of indigenous companies in the oil and gas industry. This concept can be viewed as having mainly evolved from the Niger Delta region area that is commonly known for conflicts [35], which later spread to the entire country. In 1989-2000, the government introduced the indigenization policy to prevent conflict and crises especially within the oil-producing communities. The policy was administered to involve the allocation of oil acreages to indigenous oil companies by regulatory authorities [35]. This policy was based on guidance criteria which were interpreted through a broad discretion. The criteria involved four basic principles: firstly, the grants were made on a discretionary basis based on existing seismic data; secondly, ownership of the grantee company truly resided with Nigerians as beneficial owners and not as nominees of foreign entities; thirdly, a grantee was deemed to be the operator with a Nigerian managing director; and finally, the grantee was entitled a to a farm-out with or without the existence of a technical agreement. Most importantly, the grantee could have foreign technical partners, but those partners must have no more than $40 \%$ participating interests. Although a very laudable policy, it was heavily criticized as having several irregularities, as noted in the findings of the "Christopher Kolade Enquiry" [41]. The issues identified mainly concerned levels of transparency in respect of the allocation of participation rights, following which 31 oil production licenses that had been awarded to indigenous companies were revoked in February 2000. Other countries, such as Liberia and Sierra Leon, have incorporated LC rules to achieve post-conflict harmony, as was discussed by Michael Warner (2011) [9]. Also, Latin American countries have often resolved conflicts through LC rules [42].

Correspondingly, environmental distortions accrue to daily lives, especially in areas where explorations operations occur, hence the need for environmental protection. Nevertheless, in principle, environmental rationales are never at the forefront of implementing LC, but in practice they always steer discussions of social politics, which will be discussed in the following chapter, rules of engagement.

\section{Rules of Engagement}

These rules determine the degree (whether binding or non-binding), circumstances, and conditions of developing and implementing LC objectives. The common forms of binding mandates are pursued within legislative instruments (law, decrees, and hydrocarbon agreement) while non-binding instruments include policies, guidelines, and initiatives. Most oil-producing nations evaluated tend to formulate them either as a provision within a legislative instrument (e.g., a regulation or decree) or a provision under a hydrocarbon agreement (for example a production-sharing agreement (PSA) or license) [11].

\subsection{Legislative Instruments}

Technically, before committing funds to any project, including developing LC requirements, investors consider whether the laws and contracts of a given country contemplate their rights and responsibilities, or whether the rules are likely to be defined clearly, respected, or even enforced effectively. Thus, the choice of regime determines the manner of operations. Currently, petroleum-producing countries choose between a regime in which most issues relating to petroleum operations are fixed in a substantive statute, often referred to as petroleum law or a regime, which leaves a wider range of issues to be agreed in a granting instrument (contractual agreement) [43]. Often, 
in the extreme form of one option, if an LC provision is detailed then it is not negotiable other than the bidding parameter of either work or cash programs. At the other extreme end, there is no petroleum law, and upstream operations are based on entirely negotiated contracts. Nonetheless, the jurisdictions evaluated have incorporated both schemes, where statutory (laws) and contracts have been utilized. Hence, the need to evaluate both segments.

\subsubsection{Statutory}

This article maintains that statutory clauses, whether substantive or procedural, create a mandatory rule to develop LC. Thus, they need to be distinguished from non-mandatory clauses (often negotiable). A rule is determined as mandatory if laid down by specific legislation. Their mandatory nature may either be expressly stated or inferred by way of interpretation. In definition, the concept that a rule is mandatory implies that the rule is not subject to contradiction even by way of an agreement in that it is a legal rule that is in all cases binding and cannot be departed from despite having an agreement between the parties concerned [1]. Mandatory LC requirements are often linked to the conditions for the entry and continued operation of the investment [5]. The investor must agree to them at the time of making its investment and/or during the period in which an investor continues to operate [4]. Non-mandatory LC, on the other hand, are often linked to access to certain advantages, such as tax exemptions or subsidies by the host country [4]. Thus, in theory, the investor could decide not to comply with them. Nevertheless, the distinction between these two categories is not always clear, since some incentives do not give the investor the possibility of refusing to comply with the LC because of the attractiveness of incentives offered [4].

\section{Substantive Petroleum Law}

The substantive law that governs the exploration and development of petroleum activities is often referred to as the Petroleum law. It is the primary law used to determine the rights and responsibilities of parties, including the development of LC requirements. Thus, the law would normally define what the LC requirements are (if any) and the applicability of the measure (at what stage of operations the LCs need to be implemented. Thus, LC development would be governed as a fixed provision within a law (either as a chapter or defined in interpretation) and a procedural law (regulation) will be formulated to support its development.

Historically, most petroleum laws did not have a chapter that specifically dealt with "LC development". The "term" LC is rather a recent phenomenon in the oil and gas sectors. This can be attributed to the fact that most petroleum laws are identical in that they move from one jurisdiction to another with minimal changes [44]. Thus, the common rule in the sector was to draft general terms that read "use of local goods and services" or "hiring, integration and training of local personnel", which presently is interpreted to mean LC requirements. Often, the provisions were dealt with separately under different sections or chapters, for instance, Articles 27 and 86 of the Angola Petroleum Activities (2004) dealt with issues relating to the use of local personnel, goods, and services. Specifically, the law requires that all investors acquire consumer goods of national production, and contract with local service providers with the same or approximately the same quality. Also, it is mandatory to consult locals. Additionally, investors are required to employ only Angolan citizens in all categories and functions, except if there are no Angolan citizens in the national market with the required qualifications and experience.

The rationale to include these clauses within the substantive law was twofold. Firstly, governments desired to establish the mandatory nature of the rules used (both pre-investment and post investment). Pre-investment LC are normally expected to be achieved at the time of entering operations, often at bidding stages, while post LC requirements are imposed after an investment has occurred and are mostly for the purposes of the continuation of a project [4]. This distinction is important in two levels: one is the legal ramification that subsequently follows if there is a breach. Thus, pre-investment rules within a substantive law are known to the investor in advance, therefore if there is a failure to fulfil his 
obligation under it he is said to be in breach of the rules and his contract can be terminated. For instance, the Angolan law petroleum activities law requires that if the investor does not comply then he is in breach of the provisions of the Article and thus his agreement with the state shall be deemed null and void. Two, LCs imposed post investment, especially mandatory LCs, are more likely to breach the host state's commitments in an investment or trade treaty (a scope beyond this article).

Secondly, the rationale to include LC provisions within a substantive law was that governments felt that oil companies were reluctant to implement LC if it was contractual or within a policy. This is because the implementation of LCs, at least in the initial stages, interrupts operations and eventually leads to an increase of operation cost. Thus, the introduction of mandatory rules creates a binding obligation on the investors to meet the needs of the society irrespective of the cost. As an illustration, prior to introducing the "Law of Subsoil and Subsoil Use", the government of Kazakhstan passed a decree through the ministry in the summer of 2002, for which all subsoil users were obliged to procure Kazakh goods based on state procurement rules. This did not actually materialize in practice, as most subsoil users kept purchasing Kazakh goods or services at their discretion. In turn, the government introduced the "Law of Subsoil and Subsoil Use" making LC purchases obligatory, and ever since almost all subsoil users have carried out their procurement under the state-regulated procedure [45]. Furthermore, in Nigeria, the government initially opted for an LC policy introduced in the year 2006. It is argued to have constituted a comprehensive framework on how LC should be implemented at the time that resources will be extracted to secure the interests of the locals [35]. Surprisingly, by the year 2010, not much success had been achieved due to the voluntary nature of the policy. This prompted the Nigerian government to introduce a prescriptive LC law, also known as the "Nigerian Oil and Gas Industry Content Development Act, 2010".

\section{Substantive Local Content Law}

Although primary legislation, it is a separate substantive law that specifically deals with LC developments; for instance, the Nigeria Oil and Gas Content Industry Development Act 2010. The Act provides that all petroleum activities must comply with the mandates outlined in the law. The law is not clear on several issues, for instance, how these activities will apply to new projects, even though the government does not issue any new oil mining leases. Hence, it appears that its application will be implemented retroactively. The next question then becomes at what stage or duration of investment should the requirements be implemented.

The challenges with a substantive law as opposed to an integrated LC provision within a petroleum law are numerous. Generally, a substantive law ought to operate prospectively for various reasons in that it should not affect existing contractual obligations or prompt the reopening of past, closed, and completed transactions, or it should not affect accrued rights and remedies, including those affecting procedure. Thus, a substantive law that is applied retrospectively completely changes the contractual relationships, rights, remedies, and procedure that previously existed between a state and IOCs. Therefore, the Nigerian content Act can be argued as inherently breaching the rule of law in accord with Lord Denning's words "a substantive law is generally prospective, thus the rule in general is applicable where the object of the statute is not to affect the vested rights or impose new burdens or to impair existing obligations". Thus, in the discussion of any rule laid down in new legislation (Act/Rule) affecting existing rights or creating new obligations, it should be regarded as applying prospectively. For instance, the Nigeria Content Act indicates provides several changes (mostly negative towards an investor); it aggravates offences of LC by bringing in new categories of offences. Also, it has extended punishments and penalties, as noted in section 68 of the Act, which provides that where an investor commits an offence, the investor is liable upon conviction to a fine of five per cent of the project sum for each project in which the offence is committed, or the cancellation of the project. Moreover, the Act has altered the processes for bidding in the Nigerian petroleum industry, and section 3(3) currently requires that the Nigeria content plan of development is to become the major criteria for 
bidding. Also, in the awarding of any oil licences (lifting, oil field), first consideration must be given to Nigerians.

In addition, LC is not an isolated issue but a concept that straddles several sectors, rationales, and instruments as discussed above. Therefore, discussing LC in isolation presents a misguided aspect of the concept itself and more so of the sector. Additionally, an isolated LC may be counterproductive if specific segments with higher potential for linkages are not identified, or if the local capacity is not assessed against other existing rules and the possibility of having parallel institutions implementing the same concept arises. This brings about the challenge of converging differing interests that often conflict as opposed to converge. Most countries in the petroleum sectors as evaluated prefer to formulate LC either under the petroleum law or in form of a petroleum title with an annexed regulation to indicate the way it will be implemented.

\section{Procedural Law}

At present, detailed regulations and decrees are enacted to administer and enforce the substantive petroleum law. Thus, procedural law provides the state with the machinery to enforce the enacted substantive petroleum laws. In relation to LC developments, these laws feature how LCs should be implemented in practice, and what method and means is to be administered. The compliance aspect of LC is undertaken through succession plans, annual reports, and others, often presented to the ministry in charge of development and supervision. Important is that the implementation of LC is accompanied by the establishment of a strong and autonomous regulatory agency, which is essential to implement technical rules in infrastructure industries.

Although not as pertinent as substantive law, procedural laws are enacted and are presumed to apply retrospectively unless such a construction is textually inadmissible. They help define the concept within a broader context. This enlarged scope on occasion creates an array of issues, such as on state and equity participation, technology transfer, incorporation of joint ventures, and research and development, signifying a more detailed and rigid law to support objectives.

\subsubsection{Contractual Agreements}

Contractual agreements have been historically utilized to negotiate and confer different rights and obligations, including the use of local personnel and goods and services. These agreements include concession, production sharing agreements, and risk service contracts. Provisions relevant to LC developments were structured under clauses such as "employment and training" and "use of local goods and services".

\section{Concession}

As referenced by the early petroleum concessions, the rationale behind a sovereign nation entering an arrangement with an IOC is to capture investments that would benefit the local economy [43]. This is often undertaken by acquiring capital to develop the country's viable resources and achieve technology transfer, which would enhance the growth of local industry [17]. This approach is often adopted to provide jobs in the short term while training local citizens to operate the industry long term [43]. Although there are varied concessions, the most commonly used is the "modern concession". This form of agreement tends to grant IOCs exclusive rights to explore, develop, sell, and export oil or minerals extracted from a specified area for a fixed period. Under this agreement, the understanding is that companies compete by offering bids (cash or work programs), often coupled with signing bonuses, for the license to such rights [43].

Historically, infant industries lacked the local skill, goods, and services adequate for prospective operations, hence concessionaires in their judgements considered to import labour, goods, or services. Later, due to nationalization sentiments, concessionaires were eventually obliged to employ locals for work which they are suited for, mostly done under the supervision of the concessionaires' skilled and commonly foreign employees. Generally, this provision was limited to approval by the institution in 
charge of such implementation, either (ministry, National Oil Company, head of state). For instance, "Clause 20" of the Brazilian concession requires that goods purchased locally must be internationally competitive, and where such goods cannot be acquired locally, then the permission of the regulator is required by the concessionaire to acquire such good or service abroad. Moreover, concessionaires had the right to import labour, goods, and services at least in the initial stages of the operations.

Notably, consolidating issues related to wages became a concern, especially where foreigners were often paid in excess compared to their local counterparts. This prompted an outcry, with locals demanding that concessionaires ought to pay fair wage as either decided by the existing laws or as agreed during the negotiations. This concern was adapted in several laws, thus mandating the concessionaire to pay a similar wage to that of the foreigners; for instance, section 86 of Petroleum Activities Law 2004 of Angola demands that the remuneration of nationals will be like that of their foreign counterparts who hold similar positions.

Presently, the promotion of the local participation has become one of the major criteria for the award of licenses. The deliberate inclusion of LC measures as bidding requirements has seen the demand for concessionaires to include LC participation to be considered for a tender. For instance, the Nigeria Content Act requires all operators to submit a Nigerian Content Plan at the time of the bid. Though, this is not a new phenomenon: in Norway in the early 1970s, at the time of bidding, foreign companies could present Norwegian authorities with lists of their operators and the Ministry in consultation with 'the goods and service office' could also add to the list of operators a local company that measured in price and quality per the demands of the IOC.

\section{Production Sharing Agreement}

First introduced in the early 1960s by Indonesia, this form of agreement has undergone extensive adjustments with resounding success at least from developing countries' perspectives. This form of agreement was based on national sentiments in the backdrop of the "New International Economic Order", where the pillars of sovereignty and industry operations merged sufficiently (though not to the satisfaction of IOCs). The PSA recognizes that the ownership of the natural resources rests in the state and the government has the full mandate to grant IOCs the right to explore, produce, manage, and operate the development of those resources.

Under a PSA, an IOC undertakes most of the financial risks of exploration and development with the view of being reimbursed for all the expenditures should there be commercial breakthrough. This carried cost will be repaid to the companies from the host government's future profits, also known as cost recovery. This element entitles the IOC to recover both current operating expenses and materials expenses for materials utilized or used in the year in which they were acquired, and capital investment expenditures for assets [34-36]. What is left is then shared accordingly among the IOC and the host government [37]. This sort of provision is applicable if the cost recovery applies for full sometime with uplifts until the total investment has been recovered. Thus, cost incurred in employment, training, and the procurement of goods and services falls within the category of expenditure, which is expected to be reimbursed through the cost recovery option. This mechanism does not only reduce the amount of money to be allocated to government, but it also delays the income that otherwise would be generated in concession modalities (royalties) or a PSA (cap on cost recoverable) [43]. In addition, it a challenge for host countries to determine what constitutes expenditure worth being reimbursed [34]. This is especially the case where IOCs' main objective is to make profit and that includes recovering at whatever cost any sunken investments.

Also, under the PSA the state plays two roles: on the one hand, it is an equal partner under a contract and must therefore fulfil its obligations under it; and, on the other hand, it preserves its public legal functions, including the formulation of laws in the public interest (such as LC laws). These roles may occasionally converge but frequently come into conflict with each other. In seeking to delineate them, the state often neglects the guiding principle of equal partnership guaranteed under the contracts to which it is a party, and only focuses on its administrative law role, thereby creating discord between 
the stakeholders. In turn, this habit disengages both policy formulation and implementation in many oil-producing nations: a phenomenon known as the 'knowing-doing gap' [46]. Hence, the nature of a PSA puts the government in conflict with itself.

It is with the above information that this article concludes that PSAs present enormous challenges in implementing LCs, at least to the host governments as compared to concession. Firstly, the cost recovery option seems to present grey areas of what constitutes an expenditure worth being reimbursed. It would be cost effective if governments use part of their proceeds to promote and secure LC objectives, which is simpler and more transparent bearing in mind that the state is the sole owner of the resources. In turn, it will enable the government to keep a larger share of the capital and profit as opposed to reimbursing IOCs. Secondly, with the current surge in social, economic, and political interests, States will continue to regulate based on these elements, and in turn it will be a difficult proposition for governments to separate their interests from those of contractual responsibility, thereby hindering the development of LC. Finally, the complexity in a PSA, which requires an intricate legal infrastructure alongside skilled professionals to undertake negotiations, unlike the concession that is mainly complex from a tax perspective, makes promoting social and economic aspects difficult to attain, especially with the inflexible nature of a PSA.

Overall, the challenges presented under agreements is that while there is provision for a clause often drafted in a couple of sentences, there is a lack of mechanisms to ensure enforcement or compliance with the measures. These clauses on LC tend to be limited in detail and lack a process for implementation. Also, contracts avoid the creation of regulatory institutions, since disputes can be resolved through courts or arbitration. This approach is rather impractical and inefficient in industries that are subject to substantial technological and economic changes. Specifically, in developing LC requirements, due to the unforeseen contingencies and other events that may arise, it may be efficient for a regulator to resolve any disputes [29]. Regardless, it appears that concession seems amenable for LC implementation, simply because there will be hardly any differences in relation to cost recovery to the IOCs, and in relation to their continued recorded profits, IOCs will comfortably provide the required essentials. There is no doubt that IOCs should secure tertiary education that conveys the interests of the industry. As was the case in Norway, the discovery of Statfjord meant that IOCs had obligations to provide the necessary educational materials, including research and development, to build the nascent industry.

\subsubsection{Limitations to Binding Rules of Engagement}

\section{Application of Substantive Laws Retrospectively Versus the Role of Stabilization Clauses}

The general aim for the incorporation of stabilization clauses is to protect against a future that may fall within demands from the host state to review the initial terms of their petroleum agreement [47]. This includes incorporating any procedural or substantive laws (including developments of LC) that impact the commercial viability of the investments [48]. Thus, if stability clauses have been negotiated to protect the project from changes in legislation, contracts may shelter investors from incorporating LC provisions [47]. Therefore, it is fair to mention that the changes brought about by LC revisions and incorporation within the laws of the host state significantly alter the economics of a project, especially when applied retrospectively.

Nevertheless, these clauses have been demanded more by investors in developing nations than they are in developed nations. Therefore, begs the question why investors are willing to invest in developed countries that do not provide stabilisation clauses but are hesitant to do so in the developing countries in their absence (a subject beyond the scope of this article). Presently, most governments in developed countries decline insertions of stabilisation clauses on the premise that they cannot bind a future government to the policies of the current administration [48]. Notwithstanding, the current emphasis from civil societies and communities in developing countries has resulted in intensified criticisms of these clauses. They are argued to undermine the willingness and the ability of the host 
state to fulfil its socio-economic obligations pursuant to international development goals, such as the "Millennium Development Goals", especially in the areas of health and safety, labour and employment rights, and the protection of cultural heritage and environment. Therefore, governments need to consider appropriate frameworks that counter this limitation to bring about socio-economic progress.

\subsection{Other Non-Binding Instruments}

\section{Policies}

Policies have been determined as the most important variable and the biggest enabler for LC development [21]. The rationale stems from the fact that policies specify objectives by embracing the interests of stakeholders in general (current and future generations, and the rights and needs of different levels of government, communities, and other stakeholders). Thus, policies tend to reflect in detail not only the rationale for LC development, but also clearly indicate the structure of the value and supply chain systems, which ensure that specific segments with higher potential for linkages are identified, while the local capacity is assessed and the constraints and pre-requisite actions are laid down [21]. In addition, policies consider other critical outlets in the development of LC content, such as the ability to manage and monitor the performance of the sector and the appropriate use of revenues for the national good [28].

These factors inform what substantive law is required that captures clearly the intention of the policy-makers. Policies ensure consistency in drafting and bring about a streamlined LC legal framework that stands to benefit governments and communities while simultaneously promoting public-private participation through enhanced engagement of stakeholders. Nonetheless, many countries have yet to consider the importance of drafting policies prior to implementing LC regulations. Governments continue to face competing priorities when designing policies that determine when, how, and by whom the resource will be developed. Research indicates that three policies appear pertinent in LC development, which is due to their ability to consider the strong interests involved between the stakeholders along the value chain. These policies include industrial policy, procurement policy, and public policies.

Firstly, the obvious policy that seems to address the challenge of improving an industrial base while promoting the interaction of all the stakeholders along the value chain, by establishing dynamic clear incentives, is industrial policy [2]. This policy must be consistent with a development strategy that is attuned to real local capabilities [2]. Also, industrial policies should be built in strategic economic models with an analysis that is designed to explain the questions they seek to answer [49]. A strategic, comprehensive industrial policy seems appropriate due to several issues, but more importantly for competitive decisions [49]. Often, they consider several issues, for example competitive decisions, by comparing other alternative measures, such as LC, tariffs, and subsidies, thereby identifying which among them is superior and would bring about high government take without unduly deterring investments [49]. Also, they consist of a social-cost benefit analysis, which indicates what impacts are likely to be encountered if measured through welfare generated by the overall project, including any restrictions. The models provide avenues to avoid the possibility of IOCs precluding local participation by undertaking an extension related to potential risk aversion.

The second policy is the option of procurement policies that deliberately consider the skill sets, goods, and services available against the backdrop of complex petroleum operations. For instance, Norway established a procurement office with technical experts to ensure that national products were often considered prior to foreign [19]. Presently, sourcing local labour, goods, and services in host countries, especially developing countries, has become a controversial subject because it regularly identifies with stifled competition as well as higher prices. Often, where a firm considers what product or service to source locally, market criteria become the determinant factor. It is argued that whatever is less expensive (quality adjusted) in the host market will be sourced locally; but what is not found at the right prices will be purchased from the global market [49]. This fundamental reasoning tends 
to deter local business from participating, at least in relation to price, quality, or service. In Angola, although the law tries to mitigate this challenge by allowing for "rule of exclusivity", the law however exacerbates the challenge by demanding that, where a service or good is of the same value (quality) and the price is not higher than $10 \%$ to that of a foreign one, then the local good or service should be considered. The lack of incentives by governments to promote higher prices prompts IOCs to devise creative ways to comply with the laws, citing ambiguous regulatory requirements. The Angolan government needs to identify reasonable ways through procurement channels to encourage IOCs to promote the development of LCs, and although initially it may not be financially viable for IOCs to consider the concept, they will with time. Often, as observed IOCs, do not display any interest in increasing the amount of local labour used in production, and are usually not eager to train new indigenous employees. Therefore, the long-term effects are transparent and indelible. For instance, local integration provides a continuous "modus operandi" in areas where resistance has been constant. In addition, other than just regulatory compliance, the eventual benefits include lower costs and reduced risks by building relationships with local actors. Hence, a comprehensive procurement model that outlines what method is likely to achieve these objectives better is necessary.

Finally, a more crucial tool is the availability of public policy that can execute different functions aligned with LC objectives. Many oil countries are associated with a low level of economic development, which is reflected in the inadequacy of social services and weak education systems that fail to consider the complexity of the offshore petroleum industry. These ailments affect LC development adversely, yet most of these governments continue to view the petroleum sector as the readiest opportunity to re-launch socio-economic benefits in isolation, with limited critical insights and major limitations of value addition. Governments' persistence on having the industry as a significant employer through rule-based policies while offering no real opportunities to ensure actual local participation that would benefit citizens is alarming. The imposition of a high quota for the supply of local goods and services is in ineffective in a context characterized by the absence of access to finance [4]. Although there are supporting policies for capacity building, which ensures actual opportunity to have locals participate, only a few elite, surrounding the president through political patronage, stand a chance to benefit $[3,50]$.

Arguably, the debate of resources as being a curse in several countries rather than a blessing is potentially increased with the role of prescriptive legislation. Thus, the requisite to reconsider developing and implementing a comprehensive regulatory approach applicable to both states as well as companies in the sector is imperative. Thus, the question of what can be done to strengthen and ameliorate such challenges facing oil and gas countries in the subject area now places an enormous task on developed and developing countries to do more meritoriously in favour of advancing the capacity for building mechanisms which promote the interest of the industry. Moving forward, while states continue to mandate ambiguous terms, it has become clear, especially to several non-governmental bodies and progressively to states and companies, that coherent regulatory approaches could better be achieved through the issue of non-binding recommendations, guidelines, and codes of ethics and conduct, as will be discussed in the next chapter.

\section{Suitability and Appropriateness Test}

Section 4 has demonstrated that governments favour command and control systems for the petroleum industry, which do not necessarily bring about the success of LC requirements. Because it relies on specific and extensive legislative rules as highlighted, it is thus prone to creative compliance, or the revision of a law when regulatory issues arise, which develop unintended outcomes of the regulation [51-53]. Also, due to their rigid nature, the choice of framework tends to ignore the necessary balance of local participation and foreign investments. This prompts a renewed debate in the domains of energy and law about the relative merits of an appropriate regulatory approach, referencing principle-based regulatory systems versus rule-based regulation [19]. This calls for a flexible regime, because rule-based regulation in relation to economic development as described in Section 4 has not sufficiently served well the rapidly changing industry $[19,54]$. This is due to the cumbersome 
nature of compliance and deterrence regulation, which ideally is not suitable for complex sectors and is least preferable for energy law and specifically petroleum activities, since they do not anticipate nor adapt in every possible situation [19]. Importantly, protectionism and government intervention schemes in the sector tend to be prescriptive and frequently lead to regulatory inconsistencies due to their rigidity. Currently, Nigeria and Angola have both adopted rigid detailed rules in regard to LC developments, where extractive companies are required by law to submit stringent local content plans detailing the number of locals to be employed, the amount goods or services to be procured locally, and the consideration for local companies in the award of oil blocks before foreign companies, without consideration of the competency levels or skill sets available [33]. This thus signifies that the rules are based more on quantity signals rather than price signals, which only facilitates the creative compliance aspect of regulation. Rule-based regulation may have been necessary to protect infant industries, for example, the formulation of Nigeria's "Petroleum Training Institute Act 1979" or Law (10/79) that mandates Sonangol Angola to employ locals and train them to build their capacity. Nevertheless, the current incorporation of LC in both Nigeria (Nigeria Oil and Gas Industry Content Development Act 2010) and Angola (Decree 17/09 Recruitment, Integration, Training, Personal Development, Human Resources, and Transfer of Knowledge) have mostly been inspired by Norway's success. In this regard, this article questions "Why have neither Nigeria nor Angola considered incorporating principle-based regulation?", which is fundamental to the success of LC developments in Norway, especially where both countries historically had applied a rule-based approach to LC development and have failed to achieve the intended outcome. Additionally, while LC requirements in general are purposive, most requirements do not clearly express the reason behind the rule, consequently indicating the fundamental difference between the rule-based and principle-based approaches.

Perhaps the consideration of a principle-based approach, also referenced as an objective-based regulation, is warranted. This is because this framework relies on broadly stated principles for which companies conduct their operations. Importantly, principles tend to express the basis for decision-making for public authorities [51]. This sort of regulation pursues an implementation of the policy objective rather a compliance objective as indicated by specific rules. This article identifies Norway's LC development as a principle-based form of regulation, based on the resemblances with the general characteristics of principles-based regulation as summarised by other legal scholars $[20,53]$. In Norway, LC principles were broadly formulated with a high level of generality. This is notable in the drafting of the ten commandments, an oil policy which ensured that the natural resources on the Norwegian Continental Shelf were applicable to a diverse range of circumstances, including extraction to benefit the entire community [54]. The intention of the principles was "to develop domestic industrial competence that would contribute to national welfare even when the extraction of oil and gas no longer stimulate growth in the economy" [17]. Thus, there exists the possibility to apply them with flexibility to a rapidly changing industry while focusing on the intended outcome. Additionally, Norway's rules contained terms that were qualitative and not quantitative. For instance, rules provided under 1972 Royal Declarations sections 53 and 54 required investors to prioritize and utilize Norwegian goods if they were competitive in price and quality. Moreover, the rules were largely behavioural standards concerned with "integrity", "skill care", "diligence", and "reasonable care" to carry out operations and manage conflicts of interest.

Arguably, the choice of regulatory approach tends to reflect the rationale and objectives of interventions. Sentimental rationales appear to favour a rigid pattern with detailed rules, while goal-oriented rationales are likely to consider a principle-based approach for regulation. Governments of oil-rich countries need consider not only the rationale, objective, or instrument for introducing LC rules but also the suitability of the mode of regulatory interventions. The need to ensure that the gap between the profits of operating companies and those of local economic interests are captured to retain value created from the industry is imperative [7]. For example, Norway's preliminary legal changes came along with local participation through joint ventures. For Norway, international co-operation was paramount, and being internationally competitive was based on continuous 
participation with foreigners. Currently, those changes have fostered the continuous development of local skills to meet short- and long-term need for employment, the procurement of locals, and the use of local manpower and local manufacturing in capital projects. Inversely, despite the preliminary and continuous legal, structural, and fiscal changes undertaken by Nigeria and Angola within a forty-year period to secure an equitable sharing platform, most Nigerian and Angolan citizens still live below the poverty line. This signifies that the modifications instituted in relation to LC developments have yet to positively reflect on common citizens [6].

\section{Conclusions}

While this article agrees with the general claim that every change in the law comes with significant economic changes to the terms of a contract to which an investor has initially agreed, nonetheless, the article also concludes that not all such changes amount to a breach of the rule of law. In particularly, this holds where the objectives mentioned relate to securing socio-economic benefits from a sector that has been pillaged with a negative track record on socio-economic benefits. Hence, objectives encapsulated within regulatory frameworks are not a sufficient rationale for revision. Thus, developing countries require more than just objectives within a regulation to accelerate the process of economic growth and sustainable development in oil-producing countries. Either way, both issues (choice of regulation and additional mechanisms) become pertinent when revising frameworks to incorporate LC that will have positive impacts on socio-economic developments.

Nevertheless, to achieve realistic goals and objectives, governments need to refrain from amending laws unilaterally, especially where the objective cited only serves the interests of the state (elite). Resource-rich governments require a combined effort of the tabling of objectives coupled with appropriate regulatory frameworks, in that while law operates to benefit the state, contract works to shelter the investor, and thus each party will appraise what works best to benefit them, but may very well fail to develop the overall objective for interventions. Thus, non-binding instruments with a broad, limitless platform, such as principles which do not invoke deregulation, but restructure the regulatory relationship from command and control to one based on responsibility, mutuality, and trust, are required to eventually help promote the rules of engagement in relation to converging these conflicting interests. This system promotes general strategies and stakeholder participation, where host countries aim at ensuring multi-stakeholder participation, including those in local communities impacted by the resource exploitation.

While revisions of laws and contracts continue to play a dominant role towards advancing a nation's objectives, such revisions should be undertaken with extreme caution not to violate international rules or impact resource investments. Subsequently, such balance can be achieved if the governments of resource-rich countries establish appropriate frameworks to capture and retain value created from the industry. This appropriate framework needs to be anchored on a principle-based approach to regulation, which seeks to implement policy objectives through principles as opposed to specific detailed rules. This type of framework can accommodate a rapidly changing industry, such as petroleum, which calls for a flexible regime for operations. This means that legal and regulatory frameworks are a vital factor in determining a country's ability to promote local realities.

Nevertheless, while binding instruments secure the objectives of LC by establishing definitive clear rules that set criteria and benchmarks, non-binding instruments promote rules for engagement. These two pillars eventually measure value retention in a local economy that could serve as an additional tool in national development planning processes. Ultimately, a good LC rule must be concerned with offering opportunities and driving innovation between local and foreign counterparts, thus yielding greater value to the sector and to the economy at large. 
Conflicts of Interest: The author declares no conflict of interest.

\section{References}

1. Wälde, T.W. Renegotiating acquired rights in the oil and gas industries: Industry and political cycles meet the rule of law. J. World Energy Law Bus. 2008, 1, 55-97. [CrossRef]

2. Acheampong, T.; Ashong, M.; Svanikier, V.C. An assessment of local-content policies in oil and gas producing countries. J. World Energy Law Bus. 2016, 9, 282-302. [CrossRef]

3. Ovadia, J.S. The dual nature of local content in Angola's oil and gas industry: Development vs. elite accumulation. J. Contemp. Afr. Stud. 2012, 30, 395-417. [CrossRef]

4. Nikièma, S.H. Performance Requirements in Investment Treaties Best Practices Series; International Institute for Sustainable Development (IISD): Winnipeg, MB, Canada, 2014.

5. Ramdoo, I. Unpacking Local Content Requirements in the Extractive Sector: What Implications for the Global Trade and Investment Frameworks? E15 Initiative: Geveva, Switzerland, 2015.

6. Ovadia, J.S. The Role of Local Content Policies in Natural Resource-Based Development. In Österr. Forschungsstiftung Für Int. Entwickl. ÖFSEEd Rohst. Entwickl. Südwind-Verl Wien; Österreichische Forschungsstiftung Für Internationale Entwicklung: Wien, Austria, 2015; pp. 37-45.

7. Sigam, C.; Garcia, L. Extractive Industries: Optimizing Value Retention in Host Countries; UNCTAD: Geneva, Switzerland, 2010.

8. Shafaeddin, M. How Did Developed Countries Industrialize? The History of Trade and Industrial Policy: The Cases of Great Britain and The USA; United Nations Conference on Trade and Development: Geneva, Switzerland, 1998.

9. Ado, R. Accounting, Accountability and Governance in Upstream Petroleum Contracts: The Case of Local Content Sustainability in the Nigerian Oil and Gas Sector. Ph.D. Thesis, Robert Gordon University, Aberdeen, UK, 2016.

10. Esteves, A.M.; Barclay, M.-A. Enhancing the benefits of local content: Integrating social and economic impact assessment into procurement strategies. Impact Assess. Proj. Apprais. 2011, 29, 205-215. [CrossRef]

11. Tordo, S.; Warner, M.; Manzano, O.; Anouti, Y. Local Content Policies in the Oil and Gas Sector; World Bank Publications, 2013; ISBN 978-0-8213-9934-7. Available online: http:/ / documents.worldbank.org/curated/ en/549241468326687019/Local-content-in-the-oil-and-gas-sector (accessed on 5 September 2017).

12. Mikesell, R.F. Foreign Investment in the Petroleum and Mineral Industries; Routledge: New York, NY, USA, 2011; ISBN 978-1-61726-044-5.

13. Barrera-Hernández, L.; Barton, B.; Godden, L.; Lucas, A.; Rønne, A. Sharing the Costs and Benefits of Energy and Resource Activity: Legal Change and Impact on Communities; Oxford University Press: Oxford, UK, 2016; ISBN 978-0-19-108098-2.

14. Hufbauer, G.C.; Schott, J.J.; Cimino-Isaacs, C. Local Content Requirements: A Global Problem; Peterson Institute for International Economics Press: Washington, DC, USA, 2013; ISBN 978-0-88132-681-9.

15. Walde, T.W. Revision of Transnational Investment Agreements: Contractual Flexibility in Natural Resources Development. Lawyer Am. 1978, 10, 265-298.

16. Walde, T.W. Investment Policies and Investment Promotion in the Mineral Industries. Oil Gas Energy Law J. OGEL 2002, 4. Available online: https://www.ogel.org/article.asp?key=2371 (accessed on 5 September 2017). [CrossRef]

17. Heum, P. Local Content Development: Experiences from Oil and Gas Activities in Norway; The Institute of Research and Economics and Business Administration: Bergen, Norway, 2008.

18. Thurber, M.C.; Hults, D.R.; Heller, P.R. Exporting the "Norwegian Model": The effect of administrative design on oil sector performance. Energy Policy 2011, 39, 5366-5378. [CrossRef]

19. Hunter, T. The role of regulatory frameworks and state regulation in optimising the extraction of petroleum resources: A study of Australia and Norway. Extr. Ind. Soc. 2014, 1, 48-58. [CrossRef]

20. Ford, C.L. New Governance, Compliance, and Principles-Based Securities Regulation. Am. Bus. Law J. 2008, 45, 1-60. [CrossRef]

21. Kazzazi, A.; Nouri, B. A conceptual model for local content development in petroleum industry. Manag. Sci. Lett. 2012, 2, 2165-2174. [CrossRef]

22. UN Economic Commission for Africa. Transformative Industrial Policy for Africa United Nations Economic Commission for Africa; United Nations: Addis Ababa, Ethiopia, 2016. 
23. Heum, P.; Quale, C.; Karlsen, J.E.; Kragha, M.; Osahon, G. Enhancement of Local Content in the Upstream Oil and Gas Industry in Nigeria: A Comprehensive and Viable Policy Approach; SNF: Nigeria, 2003; ISBN 978-82-491-0282-2. Available online: http://extrayendotransparencia.grupofaro.org/wp-content/ uploads /2014/12/Enhancement-of-LC-in-the-upstream-oil-and-gas-industry-in-Nigeria.pdf (accessed on 5 September 2017).

24. Grossman, G.M. The Theory of Domestic Content Protection and Content Preference. Q. J. Econ. 1981, 96, 583-603. [CrossRef]

25. Stone, S.; Messent, J.; Flaig, D. Emerging Policy Issues; Organisation for Economic Co-Operation and Development: Paris, France, 2015.

26. Oxford Business Group. The Report: Nigeria 2013. Available online: https://www.oxfordbusinessgroup. com/nigeria-2013 (accessed on 16 May 2017).

27. Hunter, T. Law and policy frameworks for local content in the development of petroleum resources: Norwegian and Australian perspectives on cross-sectoral linkages and economic diversification. Miner. Econ. 2014, 27, 115-126. [CrossRef]

28. Kuntze, J.-C.; Moerenhout, T. Local Content Requirements and the Renewable Energy Industry-A Good Match? Social Science Research Network: Rochester, NY, USA, 2012.

29. Decker, D.C. Modern Economic Regulation: An Introduction to Theory and Practice; Cambridge University Press: New York, NY, USA, 2014; ISBN 978-1-107-69906-9.

30. Pera, A. Deregulation and privatisation in an economy-wide context. OECD J. Econ. Stud. 1989, $159-204$.

31. Baldwin, R.; Cave, M.; Lodge, M. Understanding Regulation: Theory, Strategy, and Practice; OUP Oxford: Oxford, UK, 2012; ISBN 978-0-19-957608-1.

32. Hunter, T. Regulation of the Upstream Petroleum Sector: A Comparative Study of Licensing and Concession Systems; Edward Elgar Publishing: London, UK, 2015; ISBN 978-1-78347-011-2.

33. Ovadia, J.S. Local Content and Natural Resource Governance: The Cases of Angola and Nigeria. Extr. Ind. Soc. 2014, 1, 137-146. [CrossRef]

34. Decree 17/09 Recruitment, Intergration,Training, Personal Development, Human Resources and Transfer of Knowledge; Government of Angola: Luanda, Angola, 2009.

35. Ekhator, E.O. Public Regulation of the Oil and Gas Industry in Nigeria: An Evaluation. Annu. Surv. Int. Comp. Law 2016, 21, 43.

36. Ezeani, E.C.; Nwuke, C. Local Content and the Marginal Fields Programme: Challenges for Indigenous Participation in the Nigerian Oil Industry. Oil Gas Energy Law J. OGEL 2017, 15, 1-20.

37. Taverne, B. Petroleum, Industry and Governments: A Study of the Involvement of Industry and Governments in the Production and Use of Petroleum; Kluwer Law International: Alphen aam den Rijn, The Netherlands, 2008; ISBN 978-90-411-2663-4.

38. Bice, S.; Moffat, K. Social licence to operate and impact assessment. Impact Assess. Proj. Apprais. 2014, 32, 257-262. [CrossRef]

39. Silva, R.; Frazao, S. Angola's Petroleum Regulatory Reform/The Dawn of A New Age? Miranda Law Firm: Lisbon, Portugal, 2016.

40. Javorcik, B.S.; Spatareanu, M. To share or not to share: Does local participation matter for spillovers from foreign direct investment? J. Dev. Econ. 2008, 85, 194-217. [CrossRef]

41. Akinola, A.A. Democracy in Nigeria: Thoughts and Selected Commentaries; Rossandale Books: Lancashire, UK, 2015; ISBN 978-1-326-27086-5.

42. Viscidi, L.; Fargo, J. Local Conflicts and Natural Resources: A Balancing Act for Latin American Governments; The Dialogue: Washington, DC, USA, 2015.

43. Smith, E.E.; Dzienkowski, J.S.; Anderson, O.L.; Lowe, J.S.; Kramer, B.M.; Weaver, J.L. International Petroleum Transactions, 3rd ed.; Rocky Mountain Mineral Law Foundation: Westminster, UK, 2010; ISBN 978-1-882047-48-2.

44. A Liber Amicorum: Thomas Wälde-Law Beyond Conventional Thought; Werner, J., Ali, A.H., Eds.; CMP Publishing Ltd.: London, UK, 2009.

45. Asiago, B.C. Fact or fiction: Harmonising and unifying legal principles of local content requirements. J. Energy Nat. Resour. Law 2016, 34, 337-360. [CrossRef]

46. Martin, T. Model Contracts: A Survey of the Global Petroleum Industry. J. Energy Nat. Resour. Law 2015. [CrossRef] 
47. Waelde, T.W.; Ndi, G. Stabilizing International Investment Commitments: International Law Versus Contract Interpretation. Tex. Int. Law J. 1996, 31, 215.

48. Faruque, A. Validity and Efficacy of Stabilization Clauses: Legal Protection vs. Functional Value. J. Int. Arbitr. 2006, 23, 317.

49. Veloso, F. Local Content Requirements and Industrial Development Economic Analysis and Cost Modeling of the Automotive Supply Chain. Available online: http://msl.mit.edu/theses/Veloso_F-thesis.pdf (accessed on 17 October 2016).

50. Ramos, M.L. Angola's Oil Industry Operations; Open Society Initiative for South Africa (OSISA): Rosebank, South Africa, 2012.

51. Black, J. Forms and paradoxes of principles-based regulation. Cap. Mark. Law J. 2008, 3, 425-457. [CrossRef]

52. Black, J.; Hopper, M.; Band, C. Making a success of principles-based regulation. Law Financ. Mark. Rev. 2007, 1, 191-206.

53. Arjoon, S. Striking a Balance Between Rules and Principles-based Approaches for Effective Governance: A Risks-based Approach. J. Bus. Ethics 2006, 68, 53-82. [CrossRef]

54. Hunter, T. Legal Regulatory Framework for the Sustainable Extraction of Australian Offshore Petroleum Resources. A Critical Functional Analysis; The University of Bergen: Bergen, Norway, 2010.

(c) 2017 by the author. Licensee MDPI, Basel, Switzerland. This article is an open access article distributed under the terms and conditions of the Creative Commons Attribution (CC BY) license (http://creativecommons.org/licenses/by/4.0/). 